\title{
Teeth eruption pattern in Cantabrian chamois Rupicapra pyrenaica parva
}

\author{
Francisco J. PÉREZ-BARBERÍA and Gonzalo MUTUBERRÍA
}

\begin{abstract}
Pérez-Barbería F. J. and Mutuberría G. 1996. Teeth eruption pattern in Cantabrian chamois Rupicapra pyrenaica parva. Acta Theriologica 41: 217-221.

A teeth eruption pattern for Cantabrian chamois Rupicapra pyrenaica parva (Cabrera, 1911) was presented (Cantabrian Mountains, North of Spain). Permanent teeth eruption order was as follows: $\left(\mathrm{M}_{1} \mathrm{M}^{1}\right) \mathrm{M}_{2} \mathrm{M}^{2} \mathrm{I}_{1} \mathrm{M}_{3} \mathrm{M}^{3}\left(\mathrm{PM}^{2} \mathrm{PM}^{3}\right)\left(\mathrm{PM}_{1} \mathrm{PM}^{1}\right.$ $\left.\mathrm{PM}_{2} \mathrm{PM}_{3} \mathrm{I}_{2}\right) \mathrm{I}_{3} \mathrm{I}_{4}$. The eruption time was: $\mathrm{M}_{1}$ and $\mathrm{M}^{1}$ at $2-3$ months, $\mathrm{M}_{2}$ and $\mathrm{M}^{2}$ between 9 and 13 months, $\mathrm{M}_{3}$ and $\mathrm{M}^{3}$ between 22 and 25 months. Lower and upper premolars and $\mathrm{I}_{2}$ emerged at 25-29 months. $\mathrm{I}_{3}$ emerged at 36-37 months, and the last tooth erupting was $\mathrm{I}_{4}$, between 36 and 46 months. The early eruption in Cantabrian chamois in relation to other chamois subspecies was discussed, and it was suggested that possible advantages relate to chewing efficiency and a wider age-related use of vegetation.
\end{abstract}

Facultad de Biología, Dpto. Biología de Organismos y Sistemas, Universidad de Oviedo, 33071-Oviedo, Spain

Key words: Rupicapra pyrenaica parva, tooth eruption, aging, Cantabrian Mountains, Spain

\section{Introduction}

There are many methods used to age mammals (Klevezal and Kleinenberg 1967, Morris 1972). One of the most commonly used is the tooth eruption pattern (Caughley 1965, Hemming 1969). This method allows animals to be aged under field conditions, although it is limited to a short age range, depending on when lower and upper jaw tooth-rows are fully erupted. In chamois the most frequently used aging method is the horn growth rings (Couturier 1938, Bargagli and Lovari 1984, Pérez-Barbería et al. 1996), although other methods are useful under particular conditions (tooth wear - Pérez-Barbería 1994, cementum annuli Pérez-Barbería and Fernández-López 1996). In the literature very little information on teeth eruption in Cantabrian chamois Rupicapra pyrenaica parva (Cabrera, 1911) is currently available (Pérez-Barbería 1994) and this work only deals specifically with lower jaw tooth-row. The aim of this study has been to describe teeth eruption pattern in Cantabrian chamois, and draw comparisons with patterns for other chamois subspecies. 


\section{Study area and methods}

Between 1982 and 1994, 210 lower and 152 upper jaws of Cantabrian chamois from sport hunting, management culls and natural mortality were collected in the Cantabrian Mountains (northern Spain). Jaws were boiled in water and cleaned by hand. The sex of each specimen was recorded and aged using the birth date and death date in the case of animals younger than 1 year. The horn growth rings method was used for older animals (Pérez-Barbería et al. 1996). Birth date was taken to be the 1st May (Pérez-Barbería 1994). In both methods the month of death was rounded to the next whole month (eg an animal which died on 15 June was considered to be 2 months old). We considered that a tooth had erupted when it protruded from the alveolus in at least one jaw tooth-row (left or right) (Vigal and Machordom 1985, Simpson 1986). The use of this sort of tooth emergence is better than gingival emergence, since to observe the latter in jaw bones it is necessary that some stain remains on the tooth crown (Simpson 1986, Pérez-Barbería 1994). The eruption of each tooth was expressed as the number of animals showing the erupted tooth. The eruption time for a tooth was the period between which at least one animal and all animals of the same age showed the erupted tooth. Although data were not available for all of the months prior to full tooth-row eruption, we decided to show this information monthly, since details were lost when the data were pooled into periods. Teeth terminology adopted was that used by Couturier (1938): I - incisor, M - molar, PM - premolar. Subscripts and superscripts indicate lower and upper teeth, respectively. Lower and upper case is used to represent deciduous and permanent teeth, respectively.

\section{Results}

At 1 month of age all deciduous lower teeth had erupted, and within 2 to 3 months all deciduous upper teeth emerged. The eruption order of the permanent teeth was the following: $\left(\mathrm{M}_{1} \mathrm{M}^{1}\right) \mathrm{M}_{2} \mathrm{M}^{2} \mathrm{I}_{1} \mathrm{M}_{3} \mathrm{M}^{3}\left(\mathrm{PM}^{2} \mathrm{PM}^{3}\right)\left(\mathrm{PM}_{1} \mathrm{PM}^{1} \mathrm{PM}_{2} \mathrm{PM}_{3}\right.$ $\left.\mathrm{I}_{2}\right) \mathrm{I}_{3} \mathrm{I}_{4}$ (brackets indicate teeth erupting at the same time; Table 1). The eruption time of the teeth was: $\mathrm{M}_{1}$ and $\mathrm{M}^{1}$ at $2-3$ months, $\mathrm{M}_{2}$ and $\mathrm{M}^{2}$ at between 9 and 13 months, $\mathrm{M}_{3}$ and $\mathrm{M}^{3}$ at between 22 and 25 months of age. Lower and upper premolars and $\mathrm{I}_{2}$ emerged at 25-29 months. I 3 emerged at 36-37 months, and the last tooth erupting was $\mathrm{I}_{4}$, between 36 and 46 months. All animals older than 46 months (144 individuals) showed emergence of all permanent teeth (Table 1).

\section{Discussion}

Collecting large samples of Cantabrian chamois younger than 4 years of age and with known death date is difficult, since these animals are seldom included in hunting or management culls. Therefore, information about tooth eruption between 1 and 46 months of age was not available for all months, however, the main conclusions presented here should still be valid. All permanent teeth emerged between 36 and 46 months of age and teeth eruption pattern is therefore useful for aging chamois up to this age. Beyond this age other methods should be used (eg cementum annuli - Pérez-Barbería and Fernández-López 1996; horn growth rings - Pérez-Barbería et al. 1996). Our data indicate that up to 2 years old age can be estimated with an error of $\leq 4$ months. The eruption pattern is the unique 
Table 1. Age (in months) of eruption of permanent teeth of Cantabrian chamois Rupicapra pyrenaica parva from Cantabrian Mts (Spain). The number of animals with the type of emerged tooth is shown. $\mathrm{I}_{\mathrm{i}}$ - incisors, $\mathrm{PM}_{\mathrm{i}}$ - lower premolars, $\mathrm{M}_{\mathrm{i}}$ - lower molars, $\mathrm{PM} \mathrm{M}^{\mathrm{i}}-$ upper premolars, $\mathrm{M}^{1}$ - upper molars. $n$ is the number of jaws in each class. Slash separates the number of lower and upper jaws. "-" - no available information.

\begin{tabular}{lccccccccccccccccccccccccccc}
\hline Age & 1 & 3 & 8 & 10 & 12 & 13 & 14 & 15 & 16 & 17 & 22 & 23 & 24 & 25 & 26 & 27 & 28 & 29 & 32 & 35 & 36 & 37 & 39 & 40 & 41 & 46 \\
\hline$n$ & $2 / 2$ & $1 / 1$ & $2 / 2$ & $2 / 2$ & $2 / 2$ & $4 / 4$ & $1 / 1$ & $3 / 0$ & $1 / 0$ & $1 / 0$ & $3 / 3$ & $8 / 8$ & $1 / 1$ & $7 / 7$ & $2 / 2$ & $3 / 2$ & $3 / 2$ & $4 / 0$ & $1 / 1$ & $1 / 1$ & $3 / 3$ & $6 / 6$ & $1 / 0$ & $2 / 0$ & $2 / 0$ & $13 / 13$ \\
\hline $\mathrm{I}_{1}$ & 0 & 0 & 0 & 0 & 0 & 1 & 0 & 1 & 1 & 1 & 3 & 8 & 1 & 7 & 2 & 3 & 3 & 4 & 1 & 1 & 3 & 6 & 1 & 2 & 2 & 13 \\
$\mathrm{I}_{2}$ & 0 & 0 & 0 & 0 & 0 & 0 & 0 & 0 & 0 & 0 & 0 & 0 & 0 & 4 & 0 & 2 & 3 & 4 & 1 & 1 & 3 & 6 & 1 & 2 & 2 & 13 \\
$\mathrm{I}_{3}$ & 0 & 0 & 0 & 0 & 0 & 0 & 0 & 0 & 0 & 0 & 0 & 0 & 0 & 0 & 0 & 0 & 0 & 0 & 0 & 0 & 2 & 5 & 1 & 2 & 2 & 13 \\
$\mathrm{I}_{4}$ & 0 & 0 & 0 & 0 & 0 & 0 & 0 & 0 & 0 & 0 & 0 & 0 & 0 & 0 & 0 & 0 & 0 & 0 & 0 & 0 & 2 & 2 & 1 & 0 & 1 & 13 \\
$\mathrm{PM}_{1}$ & 0 & 0 & 0 & 0 & 0 & 0 & 0 & 0 & 0 & 0 & 0 & 0 & 0 & 1 & 1 & 3 & 2 & 2 & 0 & 1 & 3 & 6 & 1 & 2 & 2 & 13 \\
$\mathrm{PM}_{2}$ & 0 & 0 & 0 & 0 & 0 & 0 & 0 & 0 & 0 & 0 & 0 & 0 & 0 & 5 & 1 & 3 & 3 & 3 & 1 & 1 & 3 & 6 & 1 & 2 & 2 & 13 \\
$\mathrm{PM}_{3}$ & 0 & 0 & 0 & 0 & 0 & 0 & 0 & 0 & 0 & 0 & 0 & 0 & 0 & 5 & 1 & 3 & 3 & 3 & 1 & 1 & 3 & 6 & 1 & 2 & 2 & 13 \\
$\mathrm{M}_{1}$ & 0 & 1 & 2 & 2 & 2 & 4 & 1 & 3 & 1 & 1 & 3 & 8 & 1 & 7 & 2 & 3 & 3 & 4 & 1 & 1 & 3 & 6 & 1 & 2 & 2 & 13 \\
$\mathrm{M}_{2}$ & 0 & 0 & 0 & 2 & 2 & 4 & 1 & 3 & 1 & 1 & 3 & 8 & 1 & 7 & 2 & 3 & 3 & 4 & 1 & 1 & 3 & 6 & 1 & 2 & 2 & 13 \\
$\mathrm{M}_{3}$ & 0 & 0 & 0 & 0 & 0 & 0 & 0 & 0 & 0 & 0 & 3 & 7 & 1 & 7 & 2 & 3 & 3 & 4 & 1 & 1 & 3 & 6 & 1 & 2 & 2 & 13 \\
$\mathrm{PM}^{1}$ & 0 & 0 & 0 & 0 & 0 & 0 & 0 & - & - & - & 0 & 0 & 0 & 7 & 1 & 2 & 2 & - & 1 & 1 & 3 & 6 & - & - & - & 13 \\
$\mathrm{PM}^{2}$ & 0 & 0 & 0 & 0 & 0 & 0 & 0 & - & - & - & 1 & 1 & 0 & 7 & 2 & 2 & 2 & - & 1 & 1 & 3 & 6 & - & - & - & 13 \\
$\mathrm{PM}^{3}$ & 0 & 0 & 0 & 0 & 0 & 0 & 0 & - & - & - & 1 & 1 & 0 & 7 & 2 & 2 & 2 & - & 1 & 1 & 3 & 6 & - & - & - & 13 \\
$\mathrm{M}^{1}$ & 0 & 1 & 2 & 2 & 2 & 4 & 1 & - & - & - & 3 & 8 & 1 & 7 & 2 & 2 & 2 & - & 1 & 1 & 3 & 6 & - & - & - & 13 \\
$\mathrm{M}^{2}$ & 0 & 0 & 0 & 0 & 2 & 3 & 1 & - & - & - & 3 & 8 & 1 & 7 & 2 & 2 & 2 & - & 1 & 1 & 3 & 6 & - & - & - & 13 \\
$\mathrm{M}^{3}$ & 0 & 0 & 0 & 0 & 0 & 0 & 0 & - & - & - & 1 & 3 & 0 & 6 & 2 & 2 & 2 & - & 1 & 1 & 3 & 6 & - & - & - & 13 \\
\hline
\end{tabular}

Table 2. Eruption time (in months) of lower jaw teeth in Rupicapra genus. ${ }^{1}$ Eruption time is given in years.

\begin{tabular}{|c|c|c|c|c|c|c|c|c|c|c|c|}
\hline Taxa and locality & $\mathrm{M}_{1}$ & $\mathrm{I}_{1}$ & $\mathrm{M}_{2}$ & $\mathrm{I}_{2}$ & $\mathrm{M}_{3}$ & $\mathrm{PM}_{1}$ & $\mathrm{PM}_{2}$ & $\mathrm{PM}_{3}$ & $\mathrm{I}_{3}$ & $\mathrm{I}_{4}$ & References \\
\hline R. rupicapra (Europe) & 3 & 15 & 15 & 27 & 27 & 28 & 28 & 28 & $30-35$ & $38-44$ & Couturier 1938 \\
\hline R. rupicapra (Europe) & $4-5$ & 16 & $16-17$ & 28 & $28-30$ & - & - & - & $32-38$ & $35-40$ & Knauf and Schöeder 1975 \\
\hline R. rupicapra (France) & 4 & 16 & 16 & 28 & 32 & 32 & 32 & 32 & 40 & 44 & Pflieger 1982 \\
\hline $\begin{array}{l}\text { R. pyrenaica parva } \\
\text { (Cantabrian Mts, Spain) }\end{array}$ & 3 & $1^{1}$ & $1^{1}$ & $2^{1}$ & $2^{1}$ & $2-3^{1}$ & $2-3^{1}$ & $2-3^{1}$ & $3^{1}$ & $3 \rightarrow 3^{1}$ & Pérez-Barbería 1994 \\
\hline $\begin{array}{l}\text { R. pyrenaica parva } \\
\text { (Cantabrian Mts, Spain) }\end{array}$ & $2-3$ & $13-15$ & $9-10$ & $25-28$ & $22-24$ & $25-29$ & $25-29$ & $25-29$ & $36-39$ & $36-46$ & Present study \\
\hline
\end{tabular}


method providing estimations of age around months when the death date is unknown, and useful when horns are not present or damaged.

Teeth eruption pattern of Cantabrian chamois was consistent with the pattern given by other authors for the genus (Rupicapra rupicapra - Couturier 1938, Knauf and Schöeder 1975, Pflieger 1982; R. pyrenaica parva - Pérez-Barbería 1994) (Table 2), and similar to Bovidae species (Sokolova and Reshek 1961, Caughley 1965, Vigal and Machordom 1985). Generally, teeth of Cantabrian chamois erupted earlier than those of Rupicapra rupicapra (Table 2). However, these differences between patterns can be due to (1) differences in pooling of months, (2) variability in relation to sample size between studies, or (3) different eruption definitions, since several months pass between the eruption in bone surface and the eruption in the occlusal plane. On the other hand, if the differences between patterns are consistent, the early eruption in Cantabrian chamois would confer some advantages over the rest of the European chamois species. The oclussal surface and cutting edges are important parameters defining tooth chewing efficiency (McArthur and Sanson 1988, Wilding 1993, Gross et al. 1995), although these parameters are only functional when the tooth reaches the occlusal plane. Therefore, early eruption in Cantabrian chamois may confer an advantage in relation to chewing efficiency and a wider range of age-related vegetation use. However, more information is required to test this hypothesis.

Acknowledgements: This research was supported by CICYT (Comisión Interministerial de Ciencia y Tecnología Project no. 91-0911-FOR-217) and Consejería de Medio Ambiente y Urbanismo del Principado de Asturias (Grant 04-060-91). For the duration of this study the senior author held a grant from FICYT (Fundación para el Fomento en Asturias de la Investigación Científica y Tecnologíca). This paper was written at The Macaulay Land Use Research Institute, supported by funding from Programa de Becas de Formación de Personal Investigador en el Extranjero (Ministerio de Educación y Ciencia, Spain).

\section{References}

Bargagli R. and Lovari S. 1984. Age correlation between horn segments and tooth cementum annuli in the chamois (Rupicapra pyrenaica ornata) (Artiodactyla, Bovidae). Säugetierkundliche Mitteilungen 31: 179-183.

Caughley G. 1965. Horn rings and tooth eruption as criteria of age in the Himalayan thar, Hemitragus jemlahicus. New Zealand Journal of Science 8: 333-351.

Couturier M. A. J. 1938. Le chamois. Arthaud, Grenoble: 1-855.

Gross J. E., Demment M. W., Alkon P. U. and Kotzman M. 1995. Feeding and chewing behaviours of Nubian ibex: compensation for sex-related differences in body size. Functional Ecology 9: 385-393.

Hemming J. E. 1969. Cemental deposition, tooth succession, and horn development as criteria of age in Dall sheep. Journal of Wildlife Management 33: 552-558.

Knauf W. and Schöeder W. 1975. Das Gamswild. Paul Parey, Hamburg and Berlin: 1-234.

Klevezal G. A. and Kleinenberg S. E. 1967. Age determination of mammals from annual layers in teeth and bones. Academy of Science of the USSR, Severtsov Institute of Animal Morphology, Moscow: 1-128.

McArthur C. and Sanson G. D. 1988. Tooth wear in eastern grey kangaroos (Macropus giganteus) and western grey kangaroos (Macropus fuliginosus), and its potential influence on diet selection, digestion and population parameters. Journal of Zoology, London 215: 491-504. 
Morris P. 1972. A review of mammalian age determination methods. Mammal Review 2: 69-104.

Pérez-Barbería F. J. 1994. Determination of age in Cantabrian chamois (Rupicapra pyrenaica parva) from jaw tooth-row eruption and wear. Journal of Zoology, London 233: 649-656.

Pérez-Barbería F. J. and Fernández-López J. M. 1996. Using cementum annuli to estimate cantabrian chamois age. Journal of Wildlife Management 60: 62-67.

Pérez-Barbería F. J., Robles L. and Nores C. 1996. Horn growth pattern in Cantabrian chamois Rupicapra pyrenaica parva: Influence of sex, location and phaenology. Acta Theriologica 41: 83-92.

Pflieger R. 1982. Le chamois: son dentification et sa vie. Gerfaut Club-Princesse, Paris: 1-179.

Simpson H. 1986. Teeth. Cambridge University Press, Cambridge: 1-376.

Sokolova I. J. and Reshek V. L. 1961. Development of teeth and skull as indices of age in Saiga tatarica. Byulleten Moskovskogo Obshchestva Ispytateleï Prirody, Otdel Biologicheskiï 66: 77-98.

Vigal C. R. and Machordon A. 1985. Tooth eruption and replacement in the Spanish wild goat. Acta Theriologica 30: 305-320.

Wilding R. J. C. 1993. The association between chewing efficiency and occlusal contact area in man. Archives of Oral Biology 38: 589-596.

Received 20 November 1995, accepted 16 March 1996. 